УДК 343(477)

DOI https://doi.org/10.32837/pyuv.v0i5(34).639

\author{
М. I. Мірошниченко \\ orcid.org/0000-0001-8142-9340 \\ доктор юридичних наук, \\ професор кафедри теорії та історї права та держави \\ Київького національного університету ілені Тараса Шевченка
}

П. О. Мельник

orcid.org/0000-0002-8939-774X

кандидат юридичних наук,

адвокат

Ради адвокатів Вінницької області

\title{
ІНТЕГРАЦІЯ ОРГАНІЗОВАНОЇ ЗЛОЧИННОСТІ В ЕКОНОМІЧНУ СФЕРУ В УМОВАХ ПЕРЕХОДУ ДО РИНКОВОЇ ЕКОНОМІКИ В УРСР (1985-1991 РР.)
}

Постановка проблеми. Українськими вченими однозначно підтверджено факт зародження, поширення та трансформації (що зазвичай супроводжується значними структурними змінами в системі організованих кримінальних формувань) організованої злочинності в УРСР протягом 19601991 pр. Водночас у цей період склалась унікальна ситуація, коли на доктринальному, програмному, законодавчому, науковому, правовиконавчому, правозастосувальному рівнях кримінально-правової політики держави організована злочинність, що характеризується достатньо високим ступенем суспільної небезпеки, не була віднесена до деструктивних соціально-правових явищ, які об’єктивно мали б підлягати криміналізації у нормах законодавства про кримінальну відповідальність. Це значною мірою вплинуло на те, що у 80-х роках, коли на офіційному рівні було визнано існування організованої злочинності в СРСР загалом і в УРСР зокрема, її ототожнювали або з груповою злочинністю, або з економічною злочинністю. Відповідно, організована злочинність як соціально-правове деструктивне явище була зведена до поняття форм організованої злочинної діяльності або групових проявів злочинності, що кваліфікуються як самостійні злочини і в теорії кримінального права розглядаються переважно з позиції співучасті. Як видається, нормами інституту співучасті, які містить чинний Кримінальний кодекс, не можна забезпечити належний ступінь ефективності в протидії складним і повномасштабним проявам організованої злочинності.

Гіпотетично, організована злочинність - це не сукупність окремих злочинів, а організована злочинна діяльність, що одночасно пронизує систему соціальних, правових, економічних та інших відносин. Проведений в статті аналіз інтеграції організованої злочинності в економічну сферу в умовах переходу до ринкової економіки в УРСР (1985-1991 рр.) та отримані результати певною мірою є тому підтвердженням.
Стан дослідження. Порушену в статті тему частково аналізують в предметних рамках своїх досліджень, переважно спрямованих на 3'ясування природи організованої злочинності, факторів, що іï породжують, впливу номенклатурної приватизації в СРСР на інтеграцію організованої злочинності в економічну сферу діяльності, Д. Виговський, Я. Гілінський, І. Даньшин, А. Долгова, Є. Зозуля, О. Криштановська, В. Лунєєв, Н. Мацієвський, І. Медицький, Ю. Орлов, В. Шакун, О. Шкаратян та іншы. Дослідження здійснюють у контексті боротьби з груповою злочинністю, виділяють елементи організації у злочинній діяльності, а показники стану організованої злочинності включають переважно в групову злочинність. Не спостерігається чіткої тенденції до розмежування понять і явищ організованої злочинності та організованої економічної злочинності.

Мета дослідження - на основі історико-правового аналізу поширення організованої злочинності в УРСР всередині і другій половині 80 -х років минулого століття привернути увагу до питання про науково-практичну некоректність ототожнення понять і явищ організованої злочинності та організованої економічної злочинності.

Виклад основного матеріалу. Криза командно-адміністративної системи та планової економіки, що наростала десятиліттями в СРСР, загострилась всередині 80-х років минулого століття внаслідок різкого падіння цін на нафту 19851986 рр., яке стало фатальним для фінансової, а потім і політичної стабільності. Держава все частіше вирішувала фінансові питання за рахунок грошової емісії, що в умовах державного регулювання цін відгукнулося наростанням товарного дефіциту. Вище партійне керівництво нарешті усвідомило, що тільки перехід до ринкової економіки зможе вивести країну з глибокої економічної кризи.

13 червня 1990 р. Верховна Рада СРСР затвердила Постанову про концепцію переходу до регульованої ринкової економіки в СРСР [1]. 
На їі реалізацію Рада Міністрів СРСР ухвалила Постанову «Про заходи по створенню та розвитку малих підприємств», яка дозволяла юридичним i фізичним особам відкривати приватні фірми 3 використанням найманої праці [2]. Проте декларовані заходи не дали очікуваних результатів. Кризовий стан посилювався на тлі колосальних капіталовкладень в гонку озброєнь [3]. Отже, будь-які спроби покращити ситуацію в країні, не руйнуючи основ планового господарювання та не відмовляючи в амбіціях до світового лідерства, були наперед приреченими. СРСР розпався на окремі суверенні республіки.

Юридичні підвалини у реформу планової економіки почали закладатися ще всередині 80-х pp. Було видано закони «Про індивідуальну трудову діяльність» (1986р.), «Про держпідприємство» (1987 р.), «Про кооперацію» (1987 р.), «Про оренду і про кооперацію» (1988), «Про загальні засади підприємництва в СРСР» (1989р.). «Про підприємства в СРСР» (1990) тощо. Набирали чинності й інші партійно-урядові постанови та рішення, якими надавалося право державним підприємствам самостійно планувати виробничу діяльність (хоча й у межах запропонованих, але не директивно нав'язаних галузевими міністерствами показників), самостійно укладати контракти з постачальниками і споживачами, а в окремих випадках 3 іноземними компаніями. Законодавче регулювання спрямовувалось на якісні структурні зміни у народногосподарському комплексі. Створювалися асоціації, концерни, спільні з іноземними фірмами підприємства тощо.

У відповідь на реформи з Москви, Рада Міністрів УРСР 15 квітня 1987 року прийняла Постанову «Про заходи по виконанню в республіці Закону СРСР «Про індивідуальну трудову діяльність» (втратила чинність 20.071991 [4]. Спільними рішеннями політичного керівництва і уряду УРСР було закладено перші цеглинки у підвалину розвитку підприємницької ініціативи. Але зрушення відбувалися 3 великою потугою. Навіть побіжний аналіз праць з генези економіки ринкових відносин в УРСР дає підстави для висновку: адміністративно-бюрократичні бар'єри, прорахунки в податковій політиці, відсутність всебічної і стабільної фінансової підтримки з боку держави гальмували підприємництво в Україні. Молодий бізнес опинився на роздоріжжі через нестабільну нормативно-правову базу щодо підтримки підприємництва; нестачу джерел для накопичення початкового капіталу; високий рівень податків та спроби держави забезпечити перехід до ринку адміністративними методами.

Невдовзі після проголошення Декларації про державний суверенітет України (16.07.1990р.) Верховна Рада УРСР ухвалила Закон «Про економічну самостійність Української РСР»
(3 серпня 1990 р.) [5]. За народом України юридично закріплювались власність на їі національні багатства і національний дохід; децентралізація та роздержавлення економіки; повна економічна самостійність і вільне підприємництво; держава гарантувала рівні умови функціонування та захисту усіх форм власності. У 1991 році було прийнято закони про підприємництво, про зовнішньоекономічну діяльність та іншы, які б мали стимулюватипроцесприватизації.Проте,заоцінкою М. Сироти, експерти центру економічних та політичних досліджень ім. О. Разумкова дійшли висновку, що попри декларовані наміри влади, приватизація в УРСР не забезпечила ні очікуваних надходжень до бюджету, ні появи ефективних власників, ні прискореного капіталоутворення, ні залучення великих інвестицій. Для переважної кількості державних підприємств приватизація не привела до реструктуризації та модернізації, не сприяла підвищенню їхньої конкурентоспроможності [6].

Не покращилась ситуація і в суспільстві. Більшість громадян маргіналізованого та люмпенізованого комуно-більшовицьким режимом соціального простору і надалі залишались пасивними, не усвідомлювали особистої відповідальності за процеси, що відбувалися в країні. Десятиліттями тоталітарна ідеологія викорчовувала з генетичної пам'яті українців давні традиції вільної праці та демократії. Вчені Національного інституту стратегічних досліджень, характеризуючи основні риси менталітету «радянської людини», в першу чергу наголошують на ії пасивності, відсутності прагнення до свободи, до самостійності у вирішенні проблем життедіяльності власними силами; некомпетентність та непрофесіоналізм управлінців у прийнятті самостійних рішень, що нерідко співіснують з невмотивованою амбіційністю та хамством; укоріненому в суспільній свідомості патерналізмі - звичці перекладати на владу вирішення проблем; на безпорадності та сподіваннях на зовнішню допомогу у вирішенні нагальних проблем [7, с. 35]. Більшість громадян, критикуючи хабарництво, місництво, аморальність правлячої еліти, самі ставали учасниками сумнівних схем отримання та перерозподілу прибутків заради незаконного збагачення, що спричинювало криміналізацію різних сфер суспільних відносин. Каталізатором цього процесу, як не дивно, за оцінкою науковців стала ідеологія перебудови, закріплена законами СРСР та УРСР, які спрямовувались на подолання тотальної суспільної кризи. «Кримінологічно значущі заходи і погляди вітчизняних реформаторів, - пише А. Долгова, - висвітлені в документах, публікаціях, інтерв'ю. Усі вони підтверджують, що визначальні концептуальні настанови перетворень дев'яностих років передбачали використання кримінального потенціалу в ході реформ, при цьому свідомо припускаючи криміналізацію різних сфер суспільства» [8, с. 381]. 
Найактивніше підлягала криміналізації економічна сфера. В ході приватизації широкого поширення набули нові види економічних злочинів: підробка цінних паперів, недобросовісні рекламні компанії, організація фінансових пірамід, шахрайські оборудки з ваучерами тощо. Згідно з даними правоохоронних органів в ході приватизації сформувались умови для здійснення різного роду оборудок з відмивання тіньових капіталів, накопичених у попередній період розвитку тіньового сектору економіки. В руках ділків від бізнесу вони зіграли роль ефективного інструмента для придбання у власність кримінальними і напівкримінальними структурами значної частки державного і комунального майна, посилення впливу на економіку і політику, встановлення корумпованих зв'язків кримінальних структур з державними чиновниками [9, с. 237-238]. Так, за офіційними даними Держплану СРСР «тіньові доходи у сфері послуг у 1986-1987 році склали 14-16 млрд крб. Біля 18 млн людей займались індивідуальною трудовою діяльністю без реєстрації, без оформлення патентів і без оподаткування» [10].

В Україні, відповідно до директив, законів i пропозицій про шляхи подолання системної кризи, що надходили з Москви, приймалися рішення на усунення негативних причин стагнації в економіці. Проте ці заходи не тільки не усували соціально-економічних проблем, а ще більше поглиблювали процеси маргіналізації та люмпенізації суспільства, що погіршували криміногенну ситуацію в республіці. Так, посилаючись на архівні матеріали, Є. Зозуля пише, що навіть з першими реформаторськими кроками на шляху побудови незалежної та демократичної України скорочення злочинності не відбулося [11, с. 98]. За оперативними показниками в УРСР у 1990 р. питома вага злочинів по лінії карного розшуку зросла на $18 \%$, а тяжких - на $14,4 \%$. Особливу занепокоєність викликали жорстокі акти насильства, зухвалі вимагання із застосуванням зброї, тортур, вбивства, розбої, грабежі і крадіжки. Усе активніше, не зустрічаючи належного опору, відроджувались бандитські формування, агресивність яких зростала [11, с. 94 ]. Для прикладу, Д. Виговський, досліджуючи стан злочинності неповнолітніх, зауважував, що у з кінця 80-х - початку $90-\mathrm{x}$ pp. XX ст. в Україні поширились раніше маловідомі види злочинів: рекет, викрадення людей з метою отримання викупу, торгівля людьми; розповсюдження так званих «важких наркотиків», незаконний обіг вогнепальної зброї. Набула нових форм професійна злочинність. «Злодії в законі» та інші «авторитети» злочинного світу вкладали накопичені злочинним шляхом нажиті капітали в кооперативні структури. Дозволені законом експортно-імпортні операції, легальна підприємницька діяльність стали для них зручним прикриттям для здійснення масштабних махінацій 3 присвоєнням неконтрольованого прибутку, значна частина якого осідала на рахунках в іноземних банках. 3 тіні вийшли «цеховики», які налагоджували корумповані зв'язки з представниками влади та зв'язки із замаскованими організованими злочинними угрупуваннями $[12$, с. 3,14$]$. Активізувалась загальнокримінальна злочинність: кількість офіційно зареєстрованих злочинів збільшилась із 480,5 тис. у 1991 р. до 539,3 тис. у 1993 р. та 641,9 тис. у 1995 р., а загальний рівень зареєстрованої злочинності (в розрахунку на 100000 чоловік населення) у 1991 р. становив 784, у 1993 р. - 1039, у 1995 р. - 1252 злочинів [12, с. 13]. Процес криміналізації суспільства набув загрозливих масштабів та почав виходити 3-під контролю держави.

За оцінкою американського економіста, лауреата Нобелівської Премії Джона Стігліца у провалі реформ періоду перебудови значну роль відіграла правляча партійно-державна номенклатура. «Ti, хто мав би забезпечити дотримання встановлених правил поведінки та інших зобов'язань, часто самі їх порушували, створюючи проблеми для суспільства, - пише він, - і не утримались від спокуси взяти все, що можна було прихопити" $[13$, c. 13]. Наведений аргумент авторитетного вченого і досвідченого аналітика дає підстави стверджувати, що роль каталізатора у розростанні злочинності на теренах СРСР у цілому і УРСР зокрема виконала номенклатура. Безумовно, що вона прямо не втручалась у кримінальні процеси, не брала участі у здійсненні конкретних злочинів, проте зіграла роль каталізатора у «хімічній реакції розростання і поширення злочинності як реагент.

На тлі криміналізації суспільства номенклатура пережила ренесанс відродження (трансформувалась, не втрачаючи сутності, в неономенклатуру), зміцніла за рахунок того, що, володіючи монополією на державну владу, отримала ще й монополію на приватизацію державного, всенародного майна задовго до легальної приватизації на теренах СРСР, початок якої припадає лише на початок 1991 p. Вже в умовах незалежних радянських республік, згідно з висновками українського науковця Ю. Кузьменка, «...перед радянською номенклатурою відкрилися широкі економічні можливості, реалізація яких гарантувала їй повернення втраченої влади або утримання ії у своix руках. ... зміна еліт наприкінці 80-х - на поч. 90-х pp. - це ілюзія. Насправді стара номенклатура перефарбувала свій фасад із партократичного на демократичний (псевдодемократичний) і стала кістяком для формування нової еліти (неономенклатури)» [14, с. 257].

Трансформація номенклатури в неономенклатуру відбулась в ході так званої номенклатурної приватизації - латентного процесу зародження «Квазіприватної власності», що створювалась 
шляхом «...преприватизації власності та формування протокласу великих власників» [15]. В результаті сформувався сектор так званої «комсомольської економіки» (цей термін, за визначенням О. Криштановської, набув поширення в 1987 р.). Він об’єднував підприємства і фірми, створені на основі рішень партії, уряду СРСР, пленумів ЦК ВЛКСМ і ВЦ РПС. Комсомольські функціонери до початку 1989 року монополізували право розпоряджатися надприбутковими, високорентабельними із швидким обігом капіталів секторами економіки. А вже в наступні (19891992) роки сформувався так званий «клас уповноважених», що «приватизували» фінансові і управлінські структури. Як наслідок, фінансовий капітал поступово почав зосереджуватися в руках невеликої групи олігархів [16].

Таким чином, в ході номенклатурної приватизації механізми режиму вільного «підприємництва» заміщалися режимом фактично вільного доступу «підприємливих» представників номенклатури (середній вік переважно до 31 року) з різних їі ешелонів до активів державної власності та їі перерозподілу на власну користь (механізм перерозподілу розкритий в працях Н. Мацієвського [17], О. Шкаратана [18], О. Криштановськоїи[16] та інших). В результаті сформована комсомольськими функціонерами від влади система перерозподілу коштів заклала основу в збагачення двох груп майбутніх бізнесменів - керівників державних підприємств і керівників молодіжних центрів підприємницької діяльності. Керівники останніх склали первинну ланку класу "уповноважених», які користувалися безпрецедентними перевагами і привілеями у бізнесовій діяльності. Якщо в радянські часи привілеї номенклатури мали «грошово-майновий» характер і полягали у індивідуальному безоплатному користуванні часткою державного майна, особливій сфері послуг, в неофіційних і не афішованих грошових надходженнях і витратах, то в період перебудови кінця 80-х років головним привілеєм стала комерційна діяльність, за оцінкою О. Криштановської: «...дозвіл на збагачення» [16]. О. Шкаратан назвав цей процес «келейною», «паразитичною приватизацією «без зміни юридичних форм власності» [18].

Таким чином, юридично наданий державою всередині 80-х-початку 90 -х років минулого століття дозвіл на створення кооперативів, підприємницьку діяльність і на приватизацію відкрив простір для легалізації капіталів тіньового бізнесу. Численні тіньові і наближені до них структури отримали можливість зареєструвати свою діяльність офіційно.

Своєю чергою номенклатура, приватизувавши право на владу, фактично перетворилась на суб'єкта-розпорядника колективної, сукупно-приватної (корпоративно-бюрократичної) форми власності. Індивідуально-приватна власність формально була знищена, але реально загнана в підпілля, що й сприяло формуванню сектору «тіньової економіки», у сферу якої вже до кінця 1980 років було втягнуто (за різними підрахунками) ситуативно 20-30 млн людей, а на постійній основі - 3 млн [18]. Кожний 3-4-й карбованець із середньостатистичних витрат радянської сім’ї на платні послуги йшов у сферу нелегальної (тіньової) економіки [20].

В умовах розростання сектору тіньової економіки зростала корислива злочинність. 3 середини 50-х років вона збільшилась у 12-15 разів, тоді як злочинність загалом в СРСР зросла лише в 7-8 разів [21, с. 78]. Поширеними джерелами нетрудових доходів стали заробітна плата та премії, одержані шляхом перекручування та приписок звітних показників; розкрадання грошових коштів і матеріальних цінностей, державного майна; використання в корисливих цілях устаткування, транспортних засобів державних підприємств; зловживання приписками у списанні витрат в межах природних втрат продовольчих товарів тощо. Так, у 1989-1990 роках на підприємствах УРСР відомчими ревізіями було виявлено незаконних витрат на суму більше 3 млн крб, приписок та перекручування звітності на 271 підприємстві, матеріальні збитки від яких становили близько 200 тис крб. В основному крадіжки і привласнення державного майна, приписки і перекручення звітностей стали можливими через потурання керівників і особливо працівників бухгалтерського обліку, які не тільки не забезпечували належної організації внутрішньогосподарського контролю, але нерідко й самі ставали учасниками і навіть організаторами зловживань [22].

Отже, паралельно з номенклатурною незаконною, латентною приватизацією, поширювався процес легалізації незаконно і напівлегально накопичених капіталів. 3 цього приводу С. Алексєєв пише, що в процес фактичної номенклатурної приватизації «....неминуче втягнулись і ділки тіньової економіки, а разом 3 ними кримінальні структури й організації» [23]. Відбулося злиття інтересів «традиційної» кримінальної злочинності, суб'єктів «тіньової економіки», представників державної і партійної номенклатури (прямо чи опосередковано пов'язаних з тіньовими доходами), професійної злочинності і «нової злочинності» [24; 25$]$.

Новоутворений конгломерат злочинної діяльності, реалізуючи свій корисливий інтерес, поступово заповнював «пустоти» в суспільному організмі, що виникали внаслідок послаблення, або повної відсутності державного контролю в умовах впровадження у практику роботи підприємств i організацій повного госпрозрахунку і самофінансування, зміни форм власності, створення асоціацій, кооперативів, акціонерних товариств, 
концернів, орендних і спільних підприємств. За даними Міністерства фінансів України, в кінці 90-х років: «...закріпилась стійка тенденція до звільнення працівників відомчих контрольно-ревізійних служб. Тільки за 1988-1990 рр. їх чисельність в республіці скоротилась на 2 тисячі чоловік, що становило $23 \%$ від загальної кількості працюючих у цій сфері державного регулювання» [26]. За оцінкою науковців (Ю.В. Орлов, В.І. Шакун), до середини 90-х років завершилося злиття «...державних бюрократів всіх рівнів, «тіньової номенклатури», лідерів тіньового і напівтіньового підприємництва та ієрархії кримінального світу, - пише Ю. Орлов. Вони здійснюють тотальний контроль за розподілом і перерозподілом власності і економічних ресурсів, за сферою виробництва, зовнішньоекономічною діяльністю, за політикою загалом. Отримавши економічну базу із «тіні», на політичну арену починають виходити лідери кланів та їх представники і вимагають свого визнання. Вони купують ключові посади на різних рівнях влади» [27, с. 57]. В. Шакун підкреслює, що злочинні угрупування мафіозного штибу активно почали створювати потужну фінансово-економічну базу та інформаційну мережу пропаганди своєї «політичної» діяльності для перехоплення ініціативи на шляху до влади. При цьому вони спирались на молодіжні й комерційні організації та інститут депутатського лобіювання [28, с. 156].

Таким чином, у період переходу країни до ринкової економіки (середина 80-х рр.) відбулась незаконне проникнення функціонерів від номенклатури в провідні сектори економіки. Паралельно з тіні вийшли новоспечені з напівкримінальним минулим "бізнесмени» 3 метою закріпитися у найбільш прибуткових бізнесових сферах. О. Шкаратан пише, що всі ці сили перебували в стані жорсткого протистояння в прагненні необмеженого контролю за каналами отримання надприбутків. Насамкінець все завершилося злиттям «бізнесових еліт» від влади і від економіки. На вершині все ж опинилась номенклатура, в руках якої зосереджувались важелі і влади, і власності [29, с. 298]. Такого ж висновку дійшов і С. Алексєєв, зазначивши, що 3 утвердженням монополії номенклатури на приватизацію вона не втратила монополії на владу [23].

В ході номенклатурної приватизації в СРСР збагатились переважно ті соціальні сили, які згрупувавшись, не гребували кримінальними методами ведення бізнесу: а) колишня партійно-державна номенклатура; б) нова політична еліта, яка різними незаконними шляхами привласнила державні кошти; в) значна частина корпусу так званих «червоних директорів» та функціонери від комсомолу; г) тіньовики і корупціонери різних мастей; д) підприємці нової хвилі, які розпочинали бізнес 3 нуля під прикриттям кримінальний структур. Всі вони зосередили в своїх руках значні капітали, сформували або брутальною силою та підкупом захопили найбільш прибуткові сфери економіки країни.

Архівні матеріали засвідчують, що в Україні номенклатурна приватизація нічим не відрізнялась від «центру» [30; 31]. Про це пише український науковець О. Тимчук, підкреслюючи, що в 90-х рр. ХХ ст. злочинна приватизація, зрощування бізнесу, криміналітету та влади в умовах олігархічного напівавторитарного режиму в УРСР створили надзвичайно сприятливе підгрунтя для зростання злочинності в усіх i формах та проявах [32].

У 1985-1991 роках в УРСР від номенклатурної приватизації найбільшу вигоду отримали функціонери державного і партійно-комсомольського активу. Завдяки монополії на державну владу номенклатура в незаконний спосіб узурпувала право на приватизацію державної власності. Легальна приватизація, яка розпочалась у 1991 році, надійно закріпила номенклатурну власність, що мала яскраво виражений кримінальний характер [33]. Відбулась своєрідна трансформація колишньої радянської номенклатури, що мала всі ознаки колективного (бюрократично-корпоративного) власника, в неономенклатуру з ознаками корпоративно-індивідуального.

Якщо взяти за основу тезу, що основною рисою організованої злочинності (яка власне вирізняє іï з інших форм злочинної діяльності) є прагнення до легалізації, слід визнати, що діяльність функціонерів від номенклатури в процесі номенклатурної, незаконної приватизації підпадає під кримінологічну характеристику організованої злочинності. Створюючи простір «комсомольської економіки» (не на основі закону, а на основі спеціальних рішень ЦК КПРС і ЦК комсомолу на чолі з чиновниками високого рангу), всі вони вчиняли злочинні дії проти свого народу при обтяжуючих обставинах, в складі організованої групи і за попередньою змовою. Водночас важливо звернути увагу на особливість кримінальної діяльності організованої злочинності. IIİ суб'єкти не обов' язково здійснюють злочини, що передбачені і караються кримінальним законом. Проте існування організованої злочинності створює найсприятливіші умови для: а) вчинення найбільш небезпечних злочинів; б) підтримки оптимального режиму для існування й поширення діяльності злочинних формувань та поглиблення їх зв'язків як у злочинному світі, так і з представниками владних структур через корупцію.

В умовах переходу УРСР до ринкової економіки відбулась інтеграція організованої злочинності (В.В. Лунєєв називає її «радянська номенклатурна корумпована організована злочинність» [33]) в економічну сферу держави. Як уже 
згадувалось, володіючи монопольним правом на державну владу, неономенклатура легалізувала ще й право на монопольне розпорядження матеріальними і трудовими ресурсами країни. Власність стала потужним джерелом політичного зміцнення і впливу кланово-корпоративних структур, що привласнили собі виняткове право претендувати на заміщення держави та виконання її функцій. За влучною оцінкою українського політолога О. Крюкова : “Джин вийшов з пляшки”: вирощені свого часу владою олігархи стали претендувати на те, щоб диктувати останній свої умови» [34, с. 47].

Автори підручника з кримінології, за редакцією О. Джужи, підкреслюють, що «У 80-ті роки склалася тріада: «тіньова» економіка + професійна злочинність + корумповані державні чиновники». Саме ця тріада, на їх думку, заклала основи організованої злочинності, як її нового найбільш небезпечного виду, що охоплює практично всі сфери, що дають прибуток [35, с. 78-92]. Отже, за логікою авторів, в основі організованої злочинності лежить корислива мотивація до збагачення. На нашу думку, аналіз організованої злочинності в контексті корисливої мотивації до злочинної діяльності не зовсім збігається з природою цього деструктивного соціально-правового явища і свідчить про схильність дослідників і надалі слідувати марксистській тезі про визначальний характер матеріального базису в життєдіяльності суспільства та домінуючій в іноземних виданнях і документах ООН тезі про організовану злочинність як явища, заснованого на комерційному інтересі.

Як видається, корислива мотивація до збагачення характерна швидше для економічної злочинності, головна мета якої, за визначенням українських дослідників О. Користіна і С. Чернявського "...отримання прибутків і надприбутків шляхом здійснення забороненої законодавством діяльності. Організована економічна злочинність - це конгломерат організованих злочинних утворень (угрупувань), різних за своєю структурою, кількісним складом, спеціалізацією та масштабами впливу» [36].

У нашому разі, якщо розглядати корисливий інтерес у збагаченні основним стержнем і організованої злочинності і організованої економічної злочинності, доходимо висновку, що ці поняття відображають одну і ту ж сутність: корисливий інтерес до збагачення, який реалізується через сукупність економічних злочинів та корупцію тощо. Проте ці явища взаємопов'язані, взаємодоповнюючі, але не заміщують одне одного. Об’єм понять «організована злочинність» $\mathrm{i}$ «організована економічна злочинність» співпадає лише у частині здійснення злочинною групою чи злочинною організацією економічних злочинів, або у разі встановлення факту корупції. Суттєва ж різниця в цих поняттях полягає в тому, що економічна злочинність - це сукупність різних видів злочинних посягань на економічні відносини, які перебувають під охороною держави. Організована злочинність - це сукупність різних видів злочинних посягань на цінності універсального, вселюдського характеру: права і свободи людини і громадянина, екологічну, громадську, національну безпеку, інтереси держави, мир і безпеку людства. Економічна злочинність є лише інструментом організованої злочинності.

Висновки. Загальна характеристика дії факторів організованої злочинності на теренах УРСР підтверджує її укоріненість у владних структурах авторитарно-бюрократичного правління номенклатури. Приватизувавши право на державну владу і на розпорядження усіма ресурсами в державі, окремі «підприємливі» представники номенклатури як колективного суб'єкта організованої злочинної діяльності в умовах кризи командно-адміністративної системи урядування та переходу до ринкової економіки узурпували ще й право на безальтернативну їхньому інтересу приватизацію державних ресурсів, що гарантовано забезпечило на перспективу монопольне становище в системі державного управління.

На прикладі УРСР доходимо висновку, що сутнісною ознакою організованої злочинності є її укоріненість у державній владі. Мета організованої злочинності - державна влада. Стратегічна ціль організованої злочинності - тотальний контроль над стратегічними ресурсами держави і суспільства, частина з яких не обов'язково приносять матеріальну вигоду (ідеологія, освіта, духовна сфера тощо). 3 огляду на вище зазначене, не зайвим буде звернути увагу на праці тих дослідників (Т.П. Коржихіна, О.І. Крюков, Ю.Ю. Фігатнер та інші), які вбачають генетичний зв'язок між партійно-радянською номенклатурою та сучасною політичною елітою. Він виражається у збереженні стилю та методів керівництва, особливостях взаємодії механізмів прийняття рішень, намаганні у будь-який спосіб «обілити» своїх, але знищити конкурентів на шляху до монопольного володіння ситуацією як на олімпі влади, так і в сфері перерозподілу матеріальних і духовних ресурсів [36; 37, с. 205-231]. Ця проблема стане ключовою у подальших дослідженнях.

\section{Jimepamypa}

1. Постановление Верховного Совета СССР «О Концепции перехода к регулируемой рыночной экономике в СССР» от 13.06.1990 № 1558-1. Российский правовой портал. http://zakon.law7.ru/base61/part5/ d61ru5187.htm.( дата звернення: 28.11.2020).

2. Постановление Совмина СССР «О мерах по созданию и развитию малых предприятий» от 08.08.1990 № 790. http://pravo.levonevsky.org/baza/soviet/sssr0788.htm.( дата звернення:28.11.2020).

3. Мирослава Смольніцька. Горбачовська перебудова як офіційний шлях до опанування радянськими громадянами приватної діяльності. 
http://resource.history.org.ua/cgi-bin/eiu/history. exe? $C 21 C O M=2$ (дата звернення: 28.11.2020).

4. Постанова Ради Міністрів УРСР «Про заходи по виконанню в республіці Закону СРСР «Про індивідуальну трудову діяльність» від 15 квітня 1987 р. № 127. URL: http://zakon2.rada.gov.ua/laws/show/ 127-87-\% D0\% BF. (дата звернення: 28.11.2020).

5. Закон УРСР «Про економічну самостійність Української РСР» від 03.08.90. Відомості Верховної Ради України. 1990. № 34. Ст. 499.

6. Сирота М.Д. Україна у геополітичному просторі третього тисячоліття. Монографія. 2-ге вид. Київ : Унів. вид-во ПУЛЬСАРИ, 2007. 216 с.

7. Власик О., Парахонський Б., Пирожков С. Людський вимір: реалії та перспективи України. Політика і час. 1995. № 2. С. 33-36.

8. Долгова А. Идеология реформ. Преступность, ее организованность и криминальное общество. М. : Российская криминологическая ассоциация. 2003. 572 с. https://studfiles.net/preview/6705603/page:31 (дата звернення: 28.11.2020).

9. Мациевский Н.С. Теневая Россия: истоки, сущность, причины, последствия: в 3 т. Томск, 2014. T. 1. 281 c. URL: https://books.google.com.ua/ books? id=cGKlAwAAQBAJ\&pg=PA250\&lpg= PA250\&dq=комсомольская +малая+приватизация+в+период+перестройкиved. (дата звернення: 28.11.2020).

10. Известия, 1987.12 декабря.

11. Зозуля Є.В. Криміногенна ситуація в Україні періоду становлення та розвитку незалежної держави. Наука. Релігія. Суспільство. 2010. № 1. С. 93-98.

12. Виговський Д.Л. Кримінальна субкультура в механізмі злочинності неповнолітніх : автореф. дис. ... канд. юрид. наук : спец. 12.00.08. Київ, 2006. 14 с.

13. Стиглиц Дж. Куда ведут реформы ( $к$ десяти летию начала переходных проиессов). Вопросы экономики. 1999. № 9. С. 19-32.

14. Кузьменко Ю.В. Правлячий клас «безкласового» радянського суспільства в умовах суспільнополітичних трансформацій 1985-1991рp. Література та культура Полісся. 2008. Вип. 44. С. 243-258.

15. Шкаратан О.И. Тип общества и характер социальных отношений в советской России. Москва : ГУ-ВШЭ, 2003. 377 c. http://politics.ellib.org.ua/ pages-3079.html (дата звернення: 28.11.2020).

16. Криштановська О.В. Анатомия российской элиты. Москва : Захаров, 2005. 384 с https://www.ereading.club/chapter.php/143030/79/ Kryshtanovskaya Anatomiya rossiiiskoii elity.html (дата звернення: 28.11 .2020$)$.

17. Мацієвський Н. Теневая Россия: истоки, сущность, последствия: в 3 т. Томск, 2014.

18. Шкаратан О.И Социология неравенства. Теория и реальность. М. : Изд. дом «Высшей школы экономики». 2012.526 с.

19. Долгова А.И. Криминология. Учебник для вузов. НОРМА, 2001. 784 с. http://zinref.ru/000 uchebniki/00600criminalistika/001 kriminologai dolgova_2001/098.htm (дата звернення: 28.11.2020).

20. Экономическая преступность в СССР: от Хрущева до Горбачева: проблемы детерминации, масштабы, формы и особенности государственного противодействия. Монография / В.П. Пашин, С.В. Богданов, С.Г. Емельянов и др. Курск, 2012. 371 с.

21. Історія України: нове бачення: У 2 -х т. В.Ф.Верстюк, О.В. Гарань, В.М. Даниленко, В.Б.Свтух, Г.В. Касьянов, М.В. Коваль, С.В. Кульчицький, Р.Г. Симоненко, Ю.І. Шаповал; під ред. В.А. Смолія. НАН України. Інститут історії України. Київ : Вид-во «Україна», 1996. Т. 2. 494 с.
22. Пропозиції до проекту закону Міністерства торгівлі УРСР від 04.04.1991. ЦДАГО. ф. 1, оп. 22, спр. 1573. арк. 26.

23. Алексеев С.С. Собрание сочинений: В 10 т. M.: Статут, 2010. Т. 9: Публицистика. 504 с. URL: https://lawbook.online/gosudarstva-pravateoriya/nomenklaturnaya-privatizatsiya-50827.html (дата звернення: 28.11.2020).

24. Костюковский Я.В. История российской организованной преступности. http://www.narcom.ru/ publ/info/494

25. Костюковский Я.В. Организованная преступность в России (На примере Санкт-Петербурга). URL: http://www.narcom.ru/publ/info/542.

26. ЦДАГО ф. 1. оп. 22 спр. 1573, арк.29.

27. Орлов Ю.В. Політико-кримінологічна теорія протидії злочинності. Харків : Діса плюс, 2016. 656 с.

28. Шакун В.І. Влада і злочинність. Київ : Гарант, 1997. $216 \mathrm{c}$.

29. Шкаратан О. Безопасность и здоровье нации в аспекте преступности. Коллектив авторов. Москва : Криминологическая ассоциация, 1996.579 с.

30. ЦДАГО ф.1., оп. 25, т. 2, арк. 458 .

31. ЦДАВО ф. 288. оп. 10, спр.634. арк. 27-53.

32. Тимчук О.Л. Злочинність в Україні: сучасний стан, тенденції, детермінація. Вісник ЗНУ. Юридичні науки. 2012. № 2. С. 223-231.

33. Лунеев В.В.Криминогенная обстановка в России и формирование новой политической элиты. Социология преступности. 1994. http://ecsocman.hse.ru/ data/503/601/1231/010_luneev_Sotsiologiya_ prestupnosti.pdf (дата зверненння: 28.111.2020).

34. Крюков O.I. Політико-управлінська еліта України як чинник державотворення. Монографія / За наук. ред. Е.А. Афоніна. Київ : Вид-во НАДУ, 2006. 252 c.

35. Кримінологія: Підручник для студентів вищих навчальних закладів / О.М. Джужа, Я.Ю. Кондратьєв, О.Г. Кулик, П.П. Михайленко та ін. ; За заг. ред. О.М. Джужи. Київ : Юрінком Інтер, 2002. 416 с.

36. Користін О.Є., Чернявський С.С. Організована економічна злочинність в Україні: сучасний стан і стратегія протидії. Юридичний часопис Національної академії внутрішніх справ. 2011. № 1. С. 78-88.

37. Коржихина Т.П., Фигатнер Ю.Ю. Советская номенклатура: становление, механизмы действия. Bопросы истории. 1993. № 7. С. 25-38.

\section{Анотація}

Мірошниченко М.I., Мельник П.О. Інтеграція організованої злочинності в економічну сферу в умовах переходу до ринкової економіки в УРСР (1985-1991 рр.). - Стаття.

Проведений у статті аналіз інтеграції організованої злочинності в економічну сферу в умовах переходу до ринкової економіки в УРСР (1985-1991 рр.) та отримані результати спрямовані на доведення авторської гіпотези, що організована злочинність - це не сукупність окремих злочинів, а організована злочинна діяльність, що одночасно пронизує систему соціальних, правових, економічних та інших відносин. Автори наголошують на некоректності і науковій неспроможності поглядів щодо ототожнення понять і явищ організованої злочинності та організованої економічної злочинності, виходячи лише з корисливого інтересу, що лежить у основі цих видів деструктивної, протиправної діяльності і доходять висновку (на прикладі УРСР), що сутнісною ознакою організованої злочинності є ïi укоріненість у державній владі. Мета організованої 
злочинності - державна влада. Стратегічна ціль організованої злочинності - тотальний контроль над стратегічними ресурсами держави і суспільства, частина 3 яких не обов'язково приносять матеріальну вигоду (ідеологія, освіта, духовна сфера тощо).

Корислива мотивація до збагачення характерна для організованої економічної злочинності, для якої головною метою є отримання прибутків і надприбутків шляхом здійснення забороненої законодавством діяльності. Проте ці поняття взаємопов'язані і взаємодоповнюючі. Об'єм понять організованої злочинності і організованої економічної злочинності співпадає у частині здійснення злочинною групою чи злочинною організацією економічних злочинів або у разі встановлення факту корупції. Суттєва ж різниця полягає в тому, що економічна злочинність - це сукупність різних видів злочинних посягань на економічні відносини, які перебувають під охороною держави. Організована злочинність - це сукупність різних видів злочинних посягань на цінності універсального, вселюдського характеру: права і свободи людини і громадянина, екологічна, громадська, національна безпека, інтереси держави, мир і безпека людства. Економічна злочинність є лише інструментом організованої злочинності.

Ключові слова: організована злочинність, організована економічна злочинність, номенклатура, неономенклатура, номенклатурна приватизація.

\section{Summary}

Miroshnichenko M.I., MelnykP.O. Integration of organized crime into the economic sphere in the transition to a market economy in the USSR (1985-1991). - Article.

The article analyzes the integration of organized crime into the economic sphere in the transition to a market economy in the USSR (1985-1991) and the results are aimed at proving the author's hypothesis that organized crime is not a set of individual crimes, but organized crime. simultaneously permeates the system of social, legal, economic and other relations. The authors emphasize the incorrectness and scientific inability of views on the identification of concepts and phenomena of organized crime and organized economic crime, based only on the selfish interest underlying these types of destructive, illegal activities and conclude (on the example of the USSR) that the essential organ is rooted in state power. The purpose of organized crime is state power. The strategic goal of organized crime is total control over the strategic resources of the state and society, some of which do not necessarily bring material benefits (ideology, education, spiritual sphere, etc.). Selfish motivation to get rich is characteristic of organized economic crime, for which the main goal is to make a profit and make a profit by carrying out activities prohibited by law. However, these concepts are interrelated and complementary. The scope of the concepts of organized crime and organized economic crime coincides in terms of the commission of economic crimes by a criminal group or criminal organization or in the case of establishing the fact of corruption. The essential difference is that economic crime is a set of different types of criminal encroachments on economic relations, which are under state protection. Organized crime is a set of different types of criminal encroachments on the values of universal, universal nature: human and civil rights and freedoms, environmental, public, national security, state interests, peace and security of mankind. Economic crime is only an instrument of organized crime.

Key words: organized crime, organized economic crime, nomenclature, neonomenclature, nomenclature privatization. 